\title{
Anadolu University, Open Education Faculty, Turkish Language and Literature Department Graduated Students' Views towards Pedagogical Formation Training Certificate, Special Teaching Methods Courses and Turkish Language and Literature Education from: Sample of Turkey
}

\author{
Mesut Bulut \\ Correspondence: Mesut Bulut, Bayburt Faculty of Education, Bayburt University, Bayburt, Turkey
}

Received: March 28, 2016 Accepted: April 2, $2016 \quad$ Online Published: April 14, 2016

doi:10.11114/jets.v4i7.1497

URL: http://dx.doi.org/10.11114/jets.v4i7.1497

\begin{abstract}
The aim of this study is to find out Anadolu University Open Education Faculty Turkish Language and Literature graduated students' views towards Pedagogical Formation Training certificate and their opinions about special teaching methods. This study has been done in one of the universities of East Karadeniz in Turkey in which the 20 Turkish Language and Literature graduated students participated in Pedagogical Formation training certificated program. The data are collected from teachers' candidate (prospective teachers) of Turkish Language and Literature who joined special teaching methods in Pedagogical Formation training program, as a result interviewing sessions had been held. During the interview, the approvals of participants have been taken into the consideration. The data collected from interviews has been analyzed according to content analysis method with emphasizing on accurate translation as possible. After approving its reliability by participants, audio recordings were shattered. The data which was collected with interviews was analyzed by content analysis method. At the end of study the teachers express that their participation in pedagogical training program and taking part in special teaching methods course helped them to overcome their deficiencies. So, especially in Turkish Language and Literature teaching they experienced difficulties in practice with the intense use of theoretical knowledge in textbooks, and are not able to develop written and oral expression skills in test-driven examination system. Accordingly at the end of Pedagogical Formation Education program it represented the efficiency of teaching methods and techniques, effective and efficient learning. So this paper signifies the practice opportunity which participants have experienced during the program and in this regard the recommendations have been suggested to the possible problems.
\end{abstract}

Keywords: distance education, pedagogical formation training, Turkish language and literature education, special teaching methods, students' feedback

\section{Introduction}

With flourishing of information age, the importance of knowledge has been increased, Depending on the meaning attributed to the concept of knowledge and science, expectations have been changed. So the skills which societies expect the individuals have been developed. Education is undoubtedly the most important fundamental elements that shape a society. As it is clear alongside the changes in every field, development in education is indispensible. The growth of modern world imposes different approaches development in language teaching field. It is up to say "Culture which is formed by national, moral and human values adopted and expanded by language and literature; so, the continuation of the nation's life is provided. Language is the corner stone of literature. While literature materially and spiritually is a kind of art which gathers all values in its contexture" (Özbay, 2002: 115). Language and literature are regarded as millstone in forming national culture. In this regard in teaching language and literature we need to take into account national unity and integrity in order to hand on cultural values. Language and literature are taught systematically in schools. While this training is given, the common values of societies; customs, beliefs, traditions, traditions and other cultural values of students' mother tongue as technicality, rules and qualifications can be spread out by the well organized language and literature. In this respect, Turkish and Turkish language and literature education as the target values for students training play important role. With the purpose of bring in such values and behaviors which are emphasized in our Constitutional Law and National Education Basic Law, Turkish Literature have been teaching in primary and secondary schools. The Turkish Literature education is domain that relies on literature education, make 
human ready for prosperous life and with relying on others lives and experiences provide mentalities, ideas, and good manner.

"Literature and education deal with human and community, complete and involve each other. Because both main concentration is on human" (Kavcar, 1999: 2). "The functions of literature education, understanding of literary works and producing new ones have been raised with two main subjects. Students' attraction in literary works, empower their knowledge and interpretation ability, prepare the ground for the birth of new works" (Taşdelen, 2006: 54). With making humanistic approaches as starting point and focusing on literature education in intercept point of literature and education they carry out two main goals, in fact with concentrating on literature they try to bring about the individual with aesthetic vision. With relying on literature, grammar and writing (composition) try to develop individual reading, writing, speaking and listening skills; so, the literature is used as an effective instrument to develop individual education. It is up to say that the individual with the help of literature education expands everyday life feeling, thinking and manners to catch the goals (Güzel, 2006: 89). Literature education has been regarded as top step of language education. It is accepted as a field which cause to the self development of individuals, establish good relationships with others, express himself effectively, and have reconciliation with nature and himself (Bulut, 2012: 14). "Literature education is a kind of art education that with use of language power and in line with comprehension / interpretation, listening / hearing, adumbration/ perception gives literary aesthetic to the text. Its main aim is to thrive the inborn sense of beauty of student, develop and enrich it, and at the end train it... The purpose of literature teacher who relies on such aims, is beside being knowledgeable and experienced one in text analysis to be creative pedagogical formation educator" (Çetişli, 2006: 83). The main point in teaching Turkish language and literature is to increase the understanding of individuals with enriching their personality, cultural understanding and creativity. Generally according to Turkish Constitutional Law and National Education Basic Law, the purpose of Language and Literature education is to bring up individuals who care for their national and mental values, have a sense of being useful to the country, get developed in moral and humanitarian aspects, enrich thought and emotion, be capable of animadvert, and have sense of literature. In this matter language education for continuing of generation, transmitting of culture, national culture, national conscious, national solidarity and for equalization is needed. In the era which technology is expanding everywhere and as a result verbal communication is relatively low, language education must be strategically taken in school contexts. Consequently teachers training policy have been emphasized from generation to generation. Training master teachers are considered as milestone of state's plan in the case of high education; therefore, it is the only effective factor in education and starting educational program. Teachers are the actors for inauguration of all reforms. Therefore, teacher training policies is essential for states and nations. It must be constantly reviewed in every society and state educational policies, and kept up with the times. Teachers are like the driver of educational train. Teaching is complicated process which needs to be in line with rapidly changing information world. In information age which builds up information society, teachers has the central role. All over the educational process, teachers need to be developed. In the society which the teachers are not under professional development, there will not be any progress, because there is a direct relationship between teacher's quality and education.

Effective and successful teacher, who know the best teaching behavior, set the goals according to his/her teaching, select the appropriate teaching approach, evaluate teaching, and in line with this behavior can set goals and can reorganize learning and teaching process (Senemoğlu, 1992). also, teachers understanding of each student's personality and psychology, creating classroom activities and managing and communicating effectively and having the ability to use technology are needed (Darling-Hammond, 2006). The main objective is to train qualified teachers in teacher training program. Qualified teachers are defined as individuals who have profession's information, field's information and general culture (Cobb, Darling-Hammond and Murangi, 1995). From 1974 in Turkey, the shock which was experienced in teachers' education and significant changes in the teacher training system has been defined as in-service training case. After1974 correspondence course has been trained many teachers by various ways as fast training, outside of school education, evening education, summer education and open education. Teachers, who are trained in this way, aren't well trained for service (Eğitimsen, 2006; Akt. Bayram, 2010: 42).

As the education is the foundation for any society every states whenever preparing development plans, primarily must consider the case of education; because the issue which survive the society, and base the foundation of society can be get only by education. In the light of scientific and technological developments in globalized world, "Change" and "development" takes place very quickly and every community is affected by this condition; because, development in any part of the world can affect other parts of world too. In a time which information is changed and developed so quickly, the education as the foundation of every society, the responsibility of government is increased in order to create equality of opportunity for any individuals in terms of education. But the important point is that we cannot highlight economical, cultural and social needs without providing the equality of opportunity. There is a direct relationship between the rise of the level of education and the level of economic prosperity. Therefore, it will be difficult in which everyone get the education in the same conditions. Therefore, especially for individuals who cannot benefit from formal 
education, open education or distance education options possibility have an importance in creating equal conditions.

Distance education, correspondence study, home study, external study, independent study, teaching at a distance, off-campus study, open learning are considered in various forms (Özkul, 2009; Akt. Höçük, 2011 ). The term of distance education includes entirely non-synonymous different terms. Some of these terms under the distance education are, distance education, correspondence study, home study, external study, independent study, teaching at a distance, off-campus study, open learning (Kaya, 2002:9). Open education is a distance education model in the basis which wasn't used generally or by little in the closed area schools. On the basis of open education, there is a basis for the use of technology for facilitating and preparing individual in self learning education. The related studies in distance education are using same concept in the sense of open education. However, there are slight differences between these two concepts. Each distance education practices may not always be open education (Kaya, 2002:14). Distance learning should be depended on traditional education practices as age, method, place and time and it is specially prepared inscribed instruments which with the help of mass media makes itself ready for education and training practices (Hizal, 1983; Henri, 1990). Distance education because of traditional learning-teaching methods limitation and in the absence of classroom activities , has been done between training scheme planner and students, and it is teaching method with specially prepared teaching units of communication and interaction through a variety of mediums (Kaya, 2002: 21-22).Distance education regardless of time and place which provide individualized training opportunities. Nowadays, with relying on communication technologies and especially through internet, it has been is carried out. (Clark and Mayer 2003:13; Akt. Baturay and Bay, 2009: 17). Distance education refers to a training system model which; students and teachers in different environments, teaching and learning activities perform the best with communications technology and postal services (İşman,1998: 23). Distance education; besides making specific organizations and practices, it is the technique which also makes a special lesson plan to teach specific techniques with or without the use of electronic systems, and with special communication methods normally is planned learning that contain teaching activities in various environment (Moore and Kearsly,1996: 2). In the context of distance education there is an alternative educational system that prepare opportunity for individual in higher education, while open education in Turkey is oriented education system which concentrate traditionally on individual out of campus study system. Open education faculty of Anadolu University with having a lot of students is one of the best which train for the distance education. Open education or distance education with allowing more people, in point of creating equality of opportunity and possibility eliminate lack of physical space, and also it is an educational system that increases learning opportunities and alternatives for target group faster in economical way. Moreover it is an education system which is in demand around the world which aims to increase learning opportunities, recognize a variety of learning opportunities, provide individuals to continue their education as well as business life, and with its economic and ergonomic aspects quickly and easily tries to access the people. This offers the advantages of open education or distance education, but the lack of face to face training, processing of course within a certain system of teacher guidance, the labor of preparing the course content and the high cost and its time consuming aspects or incomplete content due to individual differences, lack of communication in the learning and teaching motivational point or depending on the individual case, various situations or deficiencies in written and oral expression skills are considered as disadvantages for open education. Briefly distance education / training it is a way of learning, which creates educational services to a wider group, and ensures equal opportunities in education for students and teachers. With the help of various communication technologies in different places create interaction and condition for performing teaching-learning activities.

Beside Anadolu University in Turkey which fully provides distance education service, undergraduate, graduate and postgraduate programs, some courses, practices in courses can be seen in some institutions. Ankara university in Turkey, Ahmet Yesevi university, İstanbul Teknik university, Orta Middle East Technique university , İstanbul Bilgi university, 100. Y1l University, Firat University, Sakarya University, Selçuk University, Gazi University are in the list of universities which provide distance education (Höçük, 2011:7). Also Atatürk University provides distance education too (Gurbuz, 2015). At the head of employment prospects of individuals who have graduated through distance education comes teaching profession. Individuals who took distance education hoping to take the pedagogical training certificate. Open education graduated students who deprived of face to face Formal education and practice based activities, especially in the teaching profession and practices, are not adequately equipped. Students who entered with much lower scores than formal education to these universities have the lack of excellent academic credentials, skills, theoretical, methodology and technical knowledge. The remedy for such limitation will be pedagogical formation program certificate with the intention of gaining knowledge in the teaching profession.

Although there are several studies in the fields of open education or distance education, but its applicability and all their benefits and weaknesses, there aren't much comprehensive studies (Gurbuz, 2014: 241; Gurbuz, 2016). In this context, the evaluation of student opinions toward pedagogical formation training, investigation of their benefits and shortcomings and teacher training policies in the distance education seem necessary. 


\subsection{Purpose of the Research}

The purpose of this study is to identify the opinion of students about special teaching methods courses and Turkish Language and Literature teaching who took pedagogical formation program in Anadolu University, distance education faculty and candidate teachers who graduated Turkish language and literature.

\section{Method}

Research models in the context of research methods are used to analyze the data with the data collection tools.

\subsection{Research Model}

In order to find out the strategies which students use in estimated problems, closely monitor the events and the facts in working conditions, and have deep explanation and observation, qualitative research method is preferred (Y1ldirım and Şimşek, 2013). Interview was predetermined. It is defined as a research used for a serious purpose, and considered asking and answering questions based on the mutual and interactive communication process (Stewart and Cash, 1985 Akt. Yıldırım and Şimşek, 2013:105). The scope of pedagogical formation of teachers training are about their attitudes toward specific teaching methods and examine Turkish language and literature teaching effect, consider positive and negative aspects of pedagogical formation in teachers training, the effect of the specific teaching methods on teaching practice course and in this context students views who take distance education on Turkish language and literature. With relying on content analysis in analyzing data it wants teacher to ask and answer the questions naturally with purpose of finding their attitudes towards distance education and pedagogical formation program.

\subsection{Studying Group}

This study has been done in one of the universities of East Karadeniz in Turkey between 20 candidate teachers of open education faculty who graduated from Turkish language and literature, and took pedagogical formation training certificate program. In this context, the study is limited with specific teaching methods course and Turkish language and literature education. Some personal information of interviewed teachers is given below.

Table 1. The Distribution of Participants by their Gender

\begin{tabular}{lll}
\hline Gender & $\boldsymbol{f}$ & $\%$ \\
\hline Female & 12 & 60 \\
Male & 8 & 40 \\
Total & 20 & 100 \\
\hline
\end{tabular}

As it is represented in table 1, 12 female teachers and 8 male teachers with total number of 20 people participated in the study.

Table 2. The Distribution of Teachers by Their Age

\begin{tabular}{lll}
\hline Age & $f$ & $\%$ \\
\hline $\mathbf{2 3}$ & 1 & 5 \\
$\mathbf{2 4}$ & 6 & 30 \\
$\mathbf{2 5}$ and up & 13 & 65 \\
Total & 20 & 100 \\
\hline
\end{tabular}

As it is represented in table 2, according to the age distribution of teachers are $23=1,24=6,25$ and up =13; so, the total number of participants are 20.

Table 3. The Distribution of Employment or Unemployment Teachers State of Affairs

\begin{tabular}{lll}
\hline Given Answers & $\boldsymbol{f}$ & $\%$ \\
\hline Yes & 3 & 15 \\
No & 17 & 85 \\
Total & 20 & 100
\end{tabular}

As it is shown in table 3 the state of affairs in the case of employment or unemployment for teachers of research is represented as from 20 people 3 of them are working, while 17 people are unemployed.

\subsection{The Study Material and Data Collection Tool}

According to Patton the aim of study is to enter the individual's inner world. So, with respect to aim of study their perspectives are investigated (Patton, 1987). Through interviews we try to understand experiences, attitudes, thoughts, intentions, commentaries, mental senses and their ignored responses (Y1ldırım and Şimşek, 2013: 148). In this study, with the intention of find out teachers' opinion 8 semi-structured questions are prepared for interviews. In preparing questions for interview the related literature had been investigated and the related question with pedagogical formation training, Turkish Language and Literature Education, have been prepared. In the first stage, the interview form which is consisted of 12 questions have been examined by 2 experts, 4 questions were extracted from interviews and 2 questions were revised, so the number of questions in the interview reduced to 8 and it took its final shape. Prepared interview 
form after 12-week courses and ending of practices had been done between the trainees. Interviews were generally conducted in two steps. They are;

- Teachers kept fully informed regarding the interview, whenever they don't want to answer the question, they express their ideas in the form of "I have no idea".

- In addition at this stage the questions which are prepared for interview are asked, and with the purpose of getting more details additional questions are asked.

Each interview lasted approximately 25 minutes. In representing the some findings obtained from the interview some abbreviations are used. Complete forms of these abbreviations are as follows:

In the analysis of data taking from interview forms, the following coding and identification technique is used.

Q1, Q2, Q3...: the researcher's questions,

$\mathrm{T} 1, \mathrm{~T} 2, \mathrm{~T} 3 \ldots$ : the opinion of referenced people (candidate teacher)

\subsection{Collection and Analysis of Data}

In this study, for examining the validity and reliability of the context;

The interview which was done between teachers candidate through sound recording (candidate teachers) were recorded with taking into account the approval of candidates, also participants are assured in the case of their sound would be shattered after the study has been done. Recorded sound of participants (teacher candidate) were listened by participants again, and it is asked whether they want to add something. After getting accurate records of source people (teachers' candidate), after confirming its appropriateness by teachers, the data obtained under investigation had been analyzed through content analysis techniques.

Content analysis is based on certain rules of coding, and is defined as a systematic technique which can summarize some words of text in small contented categories. (Büyüköztürk, Kılıç Çakmak, Akgün, Karadeniz and Demirel, 2008). The main aim of content analysis is to reach the collected data purpose and their relationships. The first stage of content analysis is to encode data. Through content analysis, defining data, and uncovering of hidden realities will be easier. The actions taken on the basis of content analysis can be analyzed and collected through similar data in the context of specific concepts and themes and content analysis. And they should be interpreted in a way that readers understand them (Yıldırım and Şimşek, 2013: 259). Data in the context of content analysis technique categorically classified, in defined categories the obtained data were listened and monitored by expert consultation. In analyzing data the frequency distribution $(f)$ and percentages $(\%)$ are given. The data and the interviews which were taken from participants of study (teachers' candidate) directly are given in the form of citations in the study. After this stage, the findings obtained from the analysis are presented widely.

\section{Results and Reviews}

Interview data which are obtained by questions are contently analyzed by qualitative approach. The questions are asked through interview and the teachers' responses to these questions were analyzed separately and their views towards same questions were considered. We gathered the same answers under same category and by making up the themes, sections were identified and classified. The participants or source teachers (teachers' candidate) responses to the questions are presented in the tables: 


\section{Q.1. what is your main purpose of receiving pedagogical formation training?}

Table 4. Represents the answer of source people (teachers' candidate or prospective teachers) to the first question and the analysis is as follow

\begin{tabular}{|c|c|c|c|}
\hline Referenced people(teachers'candidate) & Categories & $f$ & $\%$ \\
\hline$T 1$ & Opportunity Assessment & 1 & 5 \\
\hline$T 2$ & Learning implementation & 7 & 35 \\
\hline T3 & Teaching certificate & 10 & 50 \\
\hline$T 4$ & Teaching certificate & 10 & 50 \\
\hline$T 5$ & Teaching certificate & 10 & 50 \\
\hline T6 & Teaching certificate & 10 & 50 \\
\hline$T 7$ & $\begin{array}{l}\text { To address the lack of formal } \\
\text { education }\end{array}$ & 1 & 5 \\
\hline$T 8$ & Teaching certificate & 10 & 50 \\
\hline T9 & Teaching certificate & 10 & 50 \\
\hline$T 10$ & Teaching certificate & 10 & 50 \\
\hline$T 11$ & Being officer & 1 & 5 \\
\hline$T 12$ & Learning implementation & 7 & 35 \\
\hline$T 13$ & Learning implementation & 7 & 35 \\
\hline$T 14$ & Learning implementation & 7 & 35 \\
\hline$T 15$ & Learning implementation & 7 & 35 \\
\hline$T 16$ & Teaching certificate & 10 & 50 \\
\hline$T 17$ & Teaching certificate & 10 & 50 \\
\hline$T 18$ & Teaching certificate & 10 & 50 \\
\hline$T 19$ & Learning implementation & 7 & 35 \\
\hline$T 20$ & Learning implementation & 7 & 35 \\
\hline
\end{tabular}

The source people (teachers' candidates) in answering to the question "What is your main aim of taking pedagogical formation training?

Expresses their aims as follow: T1: opportunity assessment, and T2, T12, T13, T14, T15, T19, T20 stated as "learning the implementation". In fact for teaching we need pedagogical formation training to address the lack of practices and skills. In looking for responses of T3, T4, T5, T6, T8, T9, T10, T16, T17, T18, it is clear that most of the participants looking for getting necessary certificate and entering in KPSS which are needed for teaching profession. T7 because of not being formal education graduate feel some limitation and for eliminating such limitation prefer pedagogical formation training. T11 in order to be the officer of Land Forces Command take pedagogical formation training to get the certificate.

Teachers' candidate opinions towards pedagogical formation training program are represented as follow:

T1, "I do not have any decision to be a teacher. I want to assess it as opportunity, while the government proposes such right"

T3, "My reason for applying to formation training is to achieve the best in KPSS", in other words to be real teacher it is necessary to get pedagogical formation training."

T11, "In order to be officer in Land Forces Command it is necessary to be graduated of formation training program ; so I applied for that."

T7, "my main aim of taking pedagogical formation training is to eliminate the deficiencies which we have as formal teachers."

T20, "As teacher in order to learn techniques and methods and to do my responsibilities I want to take pedagogical formation training" 
Q.2. what do you think about pedagogical formation training in a case of its effect on teaching/teacher qualification?

Table 5. Source people (teachers' candidate or prospective teachers) responses are represented in following categories

\begin{tabular}{|c|c|c|c|c|c|}
\hline Source people(teachers'candidate) & Categories & & & $f$ & $\%$ \\
\hline$T 1$ & $\begin{array}{l}\text { Pedagogical } \\
\text { needed }\end{array}$ & Formation & is & 17 & 85 \\
\hline$T 2$ & $\begin{array}{l}\text { Pedagogical } \\
\text { needed }\end{array}$ & Formation & is & 17 & 85 \\
\hline T3 & $\begin{array}{l}\text { Pedagogical } \\
\text { needed }\end{array}$ & Formation & is & 17 & 85 \\
\hline$T 4$ & $\begin{array}{l}\text { Pedagogical } \\
\text { needed } \\
\text { But it is limit }\end{array}$ & $\begin{array}{l}\text { Formation } \\
\text { ted }\end{array}$ & is & 1 & 5 \\
\hline$T 5$ & $\begin{array}{l}\text { Pedagogical } \\
\text { needed }\end{array}$ & Formation & is & 17 & 85 \\
\hline T6 & $\begin{array}{l}\text { Pedagogical } \\
\text { needed }\end{array}$ & Formation & is & 17 & 85 \\
\hline$T 7$ & $\begin{array}{l}\text { Pedagogical } \\
\text { needed }\end{array}$ & Formation & is & 17 & 85 \\
\hline$T 8$ & $\begin{array}{l}\text { Pedagogical } \\
\text { needed }\end{array}$ & Formation & is & 17 & 85 \\
\hline T9 & $\begin{array}{l}\text { Pedagogical } \\
\text { needed }\end{array}$ & Formation & is & 17 & 85 \\
\hline$T 10$ & $\begin{array}{l}\text { Pedagogical } \\
\text { needed }\end{array}$ & Formation & is & 17 & 85 \\
\hline$T 11$ & No need & & & 2 & 10 \\
\hline$T 12$ & $\begin{array}{l}\text { Pedagogical } \\
\text { needed }\end{array}$ & Formation & is & 17 & 85 \\
\hline$T 13$ & $\begin{array}{l}\text { Pedagogical } \\
\text { needed }\end{array}$ & Formation & is & 17 & 85 \\
\hline$T 14$ & $\begin{array}{l}\text { Pedagogical } \\
\text { needed }\end{array}$ & Formation & is & 17 & 85 \\
\hline$T 15$ & $\begin{array}{l}\text { Pedagogical } \\
\text { needed }\end{array}$ & Formation & is & 17 & 85 \\
\hline$T 16$ & $\begin{array}{l}\text { Pedagogical } \\
\text { needed }\end{array}$ & Formation & is & 17 & 85 \\
\hline$T 17$ & $\begin{array}{l}\text { Pedagogical } \\
\text { needed }\end{array}$ & Formation & is & 17 & 85 \\
\hline$T 18$ & $\begin{array}{l}\text { Pedagogical } \\
\text { needed }\end{array}$ & Formation & is & 17 & 85 \\
\hline$T 19$ & $\begin{array}{l}\text { Pedagogical } \\
\text { needed }\end{array}$ & Formation & is & 17 & 85 \\
\hline$T 20$ & No need & & & 2 & 20 \\
\hline
\end{tabular}

Source people (teachers' candidate) responses to the question "what do you think about pedagogical formation training in a case of its effect on teaching/teacher qualification?" are as follow: T1, T2, T3, T5, T6, T7, T8, T9, T10, T12, T13, T14, T15, T16, T17, T18, T19 in answering to the question expressed that teacher proficiency, as a factor needed for teachers qualification is essential. T4 stated that" pedagogical formation is needed; but it is limited"; so, the T4 regarded pedagogical formation as necessary issue but found it out it is limited. T11 and T20 stated that we don't need pedagogical formation to be a so called teacher; it is a profession that can be professionalized by experience. The teachers' candidates outlined their opinions a follow:

T4, "Whenever the deficiency of pedagogical formation isn't removed, it cannot be beneficial.

T2, "It is absolutely needed. It is essential to find out the possibilities of implementations which are required."

T7, "It is needed to take pedagogical formation training; so as to be a proficient teacher the deficiencies should be removed."

T11, "I think so, for being well trained and proficient teachers taking pedagogical formation training isn't needed."

T17, "of course, it is needed. For being a good educator, teachers can take pedagogical formation training."

T20, "I think we don't need it, all we need is creativity." 


\section{Q.3. what are the significant deficiency or deficiencies of Turkish language and literature education program?}

Table 6. Source people (teachers' candidate) responses to the question are categorized in following way

\begin{tabular}{|c|c|c|c|}
\hline Source people (teachers' candidate) & Categories & $f$ & $\%$ \\
\hline$T 1$ & $\begin{array}{l}\text { The lack of } \\
\text { implementation, } \\
\text { knowledge and skill }\end{array}$ & 5 & 25 \\
\hline$T 2$ & $\begin{array}{l}\text { The lack of } \\
\text { implementation, } \\
\text { knowledge and skill }\end{array}$ & 5 & 25 \\
\hline T3 & $\begin{array}{l}\text { The lack of } \\
\text { implementation, } \\
\text { knowledge and skill }\end{array}$ & 5 & 25 \\
\hline T4 & $\begin{array}{l}\text { The lack of } \\
\text { implementation, } \\
\text { knowledge and skill }\end{array}$ & 1 & 5 \\
\hline$T 5$ & $\begin{array}{l}\text { The lack of } \\
\text { implementation, } \\
\text { knowledge and skill }\end{array}$ & 2 & 10 \\
\hline T6 & $\begin{array}{l}\text { The lack of visual } \\
\text { materials in course }\end{array}$ & 1 & 5 \\
\hline$T 7$ & $\begin{array}{l}\text { Theoretical tests solving } \\
\text { approach and rote learning }\end{array}$ & 5 & 25 \\
\hline$T 8$ & $\begin{array}{l}\text { Lack of written and oral } \\
\text { skills }\end{array}$ & 2 & 10 \\
\hline T9 & $\begin{array}{l}\text { Theoretical tests solving } \\
\text { approach and rote learning }\end{array}$ & 5 & 25 \\
\hline$T 10$ & $\begin{array}{l}\text { Theoretical tests solving } \\
\text { approach and rote learning }\end{array}$ & 5 & 25 \\
\hline$T 11$ & No idea & 1 & 5 \\
\hline$T 12$ & Lack of talent and interest & 2 & 10 \\
\hline$T 13$ & $\begin{array}{l}\text { The lack of } \\
\text { implementation, } \\
\text { knowledge and skill }\end{array}$ & 5 & 25 \\
\hline$T 14$ & Lack of talent and interest & 2 & 10 \\
\hline$T 15$ & $\begin{array}{l}\text { The lack of } \\
\text { implementation, } \\
\text { knowledge and skill }\end{array}$ & 5 & 25 \\
\hline T16 & $\begin{array}{l}\text { The lack of } \\
\text { implementation }\end{array}$ & 2 & 10 \\
\hline$T 17$ & $\begin{array}{l}\text { Theoretical tests solving } \\
\text { approach and rote learning }\end{array}$ & 5 & 25 \\
\hline$T 18$ & $\begin{array}{l}\text { The lack of } \\
\text { implementation }\end{array}$ & 2 & 10 \\
\hline$T 19$ & $\begin{array}{l}\text { The lack of face to face } \\
\text { education and course } \\
\text { materials }\end{array}$ & 1 & 5 \\
\hline$T 20$ & $\begin{array}{l}\text { Theoretical tests solving } \\
\text { approach and rote learning }\end{array}$ & 5 & 25 \\
\hline
\end{tabular}

Source people (teachers' candidate or prospective teachers) responses to the following question "what is the significant deficiency or deficiencies of Turkish language and literature program?" is as follow: T1, T2, T3, T13, T15 thought that it has "the lack of implementation, knowledge and skill". T4 pointed out "The lack of face to face education and course needed materials "as the main problems. T5, T8 stated "the lack of written and oral skills" as the main problem. T6 considered "The lack of visual materials in course" as the main problem, while T7, T9, T10, T17, T20 thought that "Theoretical tests solving approach and rote learning" is the main problem. One teacher (T11) stated "no idea". T12 and T14 stated "the lack of talent and interest". T16 and T18 believed "the lack of implementation" and T19 thought "The lack of face to face education and course materials" as the main reason for creating such problems.

Teachers' candidates in considering deficiency or deficiencies of English and literature education referred to following items.

T3, "with graduating from open education faculty, I have difficulty in writing and speaking skills to express myself properly. I am planning to eliminate such deficiencies by joining to the courses."

T9, "in rote learning system, we focus on test solving approaches, So, We' have trouble in the permanence of the information" 
T11, "I think I don't have any deficiency in my field of study."

T17, "theoretically it depends more on test solving, based on its non-permanent characteristics, I think it is shortcomings."

T19, "we have problem about visual aspects of course material. Textbooks are visually terrible and it creates problems in education process."

Q4. How is it possible to deal with the problems deal with Turkish language and literature education?

Table 7. Source people (teachers' candidate), responses to the fourth question are categorized in following table

\begin{tabular}{|c|c|c|c|}
\hline Source people (teachers'candidate) & Categories & $f$ & $\%$ \\
\hline$T 1$ & Focusing on implementations & 6 & 30 \\
\hline$T 2$ & Focusing on implementations & 6 & 30 \\
\hline$T 3$ & Focusing on implementations & 6 & 30 \\
\hline$T 4$ & $\begin{array}{l}\text { Accentuating writing and } \\
\text { speaking skills }\end{array}$ & 6 & 30 \\
\hline$T 5$ & $\begin{array}{l}\text { Accentuating writing and } \\
\text { speaking skills }\end{array}$ & 6 & 30 \\
\hline T6 & Accepting high scored students & 1 & 5 \\
\hline$T 7$ & Accepting high scored students & 6 & 30 \\
\hline$T 8$ & $\begin{array}{l}\text { Student quotas should be } \\
\text { reduced }\end{array}$ & 1 & 5 \\
\hline$T 9$ & Focusing on implementations & 6 & 30 \\
\hline$T 10$ & $\begin{array}{l}\text { Accentuating writing and } \\
\text { speaking skills }\end{array}$ & 6 & 30 \\
\hline$T 11$ & No idea & 1 & 5 \\
\hline$T 12$ & $\begin{array}{l}\text { Accentuating writing and } \\
\text { speaking skills }\end{array}$ & 6 & 30 \\
\hline$T 13$ & $\begin{array}{l}\text { Accentuating writing and } \\
\text { speaking skills }\end{array}$ & 6 & 30 \\
\hline$T 14$ & $\begin{array}{l}\text { There should be diversity in } \\
\text { teaching methods and } \\
\text { techniques }\end{array}$ & 1 & 5 \\
\hline$T 15$ & $\begin{array}{l}\text { Providing opportunity for } \\
\text { having online courses }\end{array}$ & 4 & 20 \\
\hline$T 16$ & $\begin{array}{l}\text { Providing opportunity for } \\
\text { having online courses }\end{array}$ & 4 & 20 \\
\hline$T 17$ & Focusing on implementations & 6 & 30 \\
\hline$T 18$ & Focusing on implementations & 6 & 30 \\
\hline$T 19$ & $\begin{array}{l}\text { Providing opportunity for } \\
\text { having online courses }\end{array}$ & 4 & 20 \\
\hline$T 20$ & $\begin{array}{l}\text { Providing opportunity for } \\
\text { having online courses }\end{array}$ & 4 & 20 \\
\hline
\end{tabular}

We asked the teachers' candidates "How is it possible to deal with the problems dealing with Turkish language and literature education?" T1, T2, T3, T9, T17, T18 stated “Focusing on implementations". T4, T5, T7, T10, T12, T13 gave importance to" Accentuating writing and speaking skills". T6 stated that for open education faculty and Turkish language and literature department, we should take high scored students. While T8 stated "Student quotas should be reduced", T11 had no idea about it. T14 believed that "There should be diversity in teaching methods and techniques". T15, T16, T19, T20 gave weight to "Providing opportunity for having online courses".

Teachers' candidates of Turkish language and literature pointed out the following statement for eliminating the limitations:

T1, "As graduated one from open education faculty, I want to be focused on implementations. Especially old works must be considered to understand the old Turkish."

T8, "The number of students in this field should be decreased gradually. I do not want the increasing in quota. Because with increasing in the number of students the quality will be decreased and it will be difficult to assigned

T18, “We don't want to be evaluated by education base on rote learning. Because a multiple choice tests are inadequate for measuring speaking and writing skills. Implementation of intensive training will create opportunities at the forefront"

T20, "the online education creates the possibility for face to face education". 
Q.5.what is/are the advantage or advantages of special teaching methods in pedagogical formation certificate program?

Table 8 . Source people (teachers' candidate or prospective teachers) responses to the fifth question are categorized in $8^{\text {th }}$ table

\begin{tabular}{|c|c|c|c|}
\hline Source people (teachers' candidate) & Categories & $f$ & $\%$ \\
\hline$T 1$ & $\begin{array}{l}\text { Increasing participation in courses, } \\
\text { self-confidence and motivation }\end{array}$ & 5 & 25 \\
\hline$T 2$ & $\begin{array}{l}\text { learning effective and efficient } \\
\text { lessons processing }\end{array}$ & 6 & 30 \\
\hline$T 3$ & $\begin{array}{l}\text { Learning teaching methods and } \\
\text { techniques }\end{array}$ & 7 & 35 \\
\hline$T 4$ & $\begin{array}{l}\text { Learning teaching methods and } \\
\text { techniques }\end{array}$ & 7 & 35 \\
\hline$T 5$ & $\begin{array}{l}\text { learning effective and efficient } \\
\text { lessons processing }\end{array}$ & 6 & 30 \\
\hline T6 & $\begin{array}{l}\text { Learning teaching methods and } \\
\text { techniques }\end{array}$ & 7 & 35 \\
\hline$T 7$ & $\begin{array}{l}\text { Increasing participation in courses, } \\
\text { self-confidence and motivation }\end{array}$ & 5 & 25 \\
\hline$T 8$ & $\begin{array}{l}\text { Learning teaching methods and } \\
\text { techniques }\end{array}$ & 7 & 35 \\
\hline T9 & $\begin{array}{l}\text { Increasing participation in courses, } \\
\text { self-confidence and motivation }\end{array}$ & 5 & 25 \\
\hline$T 10$ & $\begin{array}{l}\text { learning effective and efficient } \\
\text { lessons processing }\end{array}$ & 6 & 30 \\
\hline T11 & No idea & 1 & 5 \\
\hline$T 12$ & $\begin{array}{l}\text { Increasing participation in courses, } \\
\text { self-confidence and motivation }\end{array}$ & 5 & 25 \\
\hline$T 13$ & $\begin{array}{l}\text { Learning teaching methods and } \\
\text { techniques }\end{array}$ & 7 & 35 \\
\hline$T 14$ & $\begin{array}{l}\text { Learning teaching methods and } \\
\text { techniques }\end{array}$ & 7 & 35 \\
\hline$T 15$ & $\begin{array}{l}\text { learning effective and efficient } \\
\text { lessons processing }\end{array}$ & 6 & 30 \\
\hline$T 16$ & $\begin{array}{l}\text { learning effective and efficient } \\
\text { lessons processing }\end{array}$ & 6 & 30 \\
\hline$T 17$ & $\begin{array}{l}\text { learning effective and efficient } \\
\text { lessons processing }\end{array}$ & 6 & 30 \\
\hline$T 18$ & $\begin{array}{l}\text { Increasing participation in courses, } \\
\text { self-confidence and motivation }\end{array}$ & 5 & 25 \\
\hline T19 & $\begin{array}{l}\text { Learning teaching methods and } \\
\text { techniques }\end{array}$ & 7 & 35 \\
\hline$T 20$ & $\begin{array}{l}\text { Learning teaching methods and } \\
\text { techniques }\end{array}$ & 7 & 35 \\
\hline
\end{tabular}

Source people (teachers' candidate) answered to "what is/are the advantage or advantages of special teaching methods in pedagogical formation certificate program?" as follow: T1, T7, T9, T12, T18 emphasized "Increasing participation in courses, self-confidence and motivation". T2, T5, T10, T15, T16, T17 stated "learning effective and efficient lessons processing". T3, T4, T6, T8, T13, T14, T19, T2O believed in "Learning teaching methods and techniques" and T11 said he/she has "no idea".

The contribution of the special teaching methods courses outlined with following views:

T2, "I learned that I need to use teaching methods in teaching. I learned how to work efficiently and effectively."

T6 "It has added a lot to me when I look at my part. I did not know teaching methods and techniques; but now I know and I believe in myself."

T7 "I learned how to motivate my students. I learned how to create the feeling of self-worth and self-confidence in the students"

T18, "There is no student who cannot learn; I got, there are teachers who cannot teach." 


\section{Q.6. what are/is the contribution /s of teaching practices' course on you?}

Table 9. Source people (prospective teachers) responses to the $6^{\text {th }}$ question are outlined as category in following table

\begin{tabular}{|c|c|c|c|}
\hline Source people (prospective teachers) & Categories & $f$ & $\%$ \\
\hline$T 1$ & $\begin{array}{l}\text { I gained experience, I defeated my } \\
\text { excitement }\end{array}$ & 11 & 55 \\
\hline$T 2$ & $\begin{array}{l}\text { I experienced and I understand the } \\
\text { importance of the teaching } \\
\text { profession }\end{array}$ & 7 & 35 \\
\hline$T 3$ & $\begin{array}{l}\text { I experienced and I understand the } \\
\text { importance of the teaching } \\
\text { profession }\end{array}$ & 7 & 35 \\
\hline$T 4$ & $\begin{array}{l}\text { I don't get that course, I was } \\
\text { exempted. }\end{array}$ & 1 & 5 \\
\hline$T 5$ & $\begin{array}{l}\text { I gained experience, I defeated my } \\
\text { excitement }\end{array}$ & 11 & 55 \\
\hline T6 & $\begin{array}{l}\text { I gained experience, I defeated my } \\
\text { excitement }\end{array}$ & 11 & 55 \\
\hline$T 7$ & $\begin{array}{l}\text { I experienced and I understand the } \\
\text { importance of the teaching } \\
\text { profession }\end{array}$ & 7 & 35 \\
\hline$T 8$ & $\begin{array}{l}\text { I experienced and I understand the } \\
\text { importance of the teaching } \\
\text { profession }\end{array}$ & 7 & 35 \\
\hline T9 & $\begin{array}{l}\text { I gained experience, I defeated my } \\
\text { excitement }\end{array}$ & 11 & 55 \\
\hline$T 10$ & $\begin{array}{l}\text { I gained experience, I defeated my } \\
\text { excitement }\end{array}$ & 11 & 55 \\
\hline$T 11$ & $\begin{array}{l}\text { It has contributed to my personal } \\
\text { development }\end{array}$ & 1 & 5 \\
\hline$T 12$ & $\begin{array}{l}\text { I gained experience, I defeated my } \\
\text { excitement }\end{array}$ & 11 & 55 \\
\hline$T 13$ & $\begin{array}{l}\text { I gained experience, I defeated my } \\
\text { excitement }\end{array}$ & 11 & 55 \\
\hline$T 14$ & $\begin{array}{l}\text { I gained experience, I defeated my } \\
\text { excitement }\end{array}$ & 11 & 55 \\
\hline$T 15$ & $\begin{array}{l}\text { I experienced and I understand the } \\
\text { importance of the teaching } \\
\text { profession }\end{array}$ & 7 & 35 \\
\hline T16 & $\begin{array}{l}\text { I gained experience, I defeated my } \\
\text { excitement }\end{array}$ & 11 & 55 \\
\hline$T 17$ & $\begin{array}{l}\text { I experienced and I understand the } \\
\text { importance of the teaching } \\
\text { profession }\end{array}$ & 7 & 35 \\
\hline$T 18$ & $\begin{array}{l}\text { I gained experience, I defeated my } \\
\text { excitement }\end{array}$ & 11 & 55 \\
\hline$T 19$ & $\begin{array}{l}\text { I experienced and I understand the } \\
\text { importance of the teaching } \\
\text { profession }\end{array}$ & 7 & 35 \\
\hline$T 20$ & $\begin{array}{l}\text { I gained experience, I defeated my } \\
\text { excitement }\end{array}$ & 11 & 55 \\
\hline
\end{tabular}

Source people (prospective teachers) answered to "what are/is the contribution of "teaching practices course on you? T1, T5, T6, T9, T10, T12, T13, T14, T16, T18, T20 stated "I gained experience, I defeated my excitement". T11 believed in "It has contributed to my personal development" while, T2, T3, T7, T8, T15, T17, T20 pointed out "I experienced and I understand the importance of the teaching profession".

Prospective teachers outlined the contribution of "teaching practices" as the course of pedagogical formation certificated program as follow:

T9, "Training can be taken with relying on the necessary information; but implementation would not be complete without learning personally, I gained experience."

T11 "There are individual differences. Therefore, individuals should be approached with different approaches. This course contributed to my personal growth" 
T15 "I know how you should act as a better teacher in the class, because as teacher I took courses practically. Whenever face with a question I know how to solve it. I learned how without distracting students to have student centered teaching."

T19, "Classroom management, analysis of student's behavior and finding out the proper strategies were developed."

Q.7. As graduated one from open education faculty Turkish language and literature department what are the differences between previous and present pedagogical formation training program?

Table 10. Source people (prospective teachers) responses to the seventh question are categorized as follow

\begin{tabular}{|c|c|c|c|}
\hline Source people (prospective teachers) & Categories & $f$ & $\%$ \\
\hline$T 1$ & $\begin{array}{l}\text { As an educator, I became more } \\
\text { conscious about my job }\end{array}$ & 3 & 15 \\
\hline$T 2$ & $\begin{array}{l}\text { I learned teaching methods and } \\
\text { techniques }\end{array}$ & 3 & 15 \\
\hline$T 3$ & I learned how to teach & 8 & 40 \\
\hline$T 4$ & $\begin{array}{l}\text { I came as a student; I became a } \\
\text { teacher candidate }\end{array}$ & 2 & 10 \\
\hline$T 5$ & $\begin{array}{l}\text { I learned teaching methods and } \\
\text { techniques }\end{array}$ & 3 & 15 \\
\hline T6 & $\begin{array}{l}\text { I learned teaching methods and } \\
\text { techniques }\end{array}$ & 3 & 15 \\
\hline$T 7$ & $\begin{array}{l}\text { He made me to look more hopefully to } \\
\text { the future }\end{array}$ & 1 & 5 \\
\hline$T 8$ & $\begin{array}{l}\text { As an educator, I became more } \\
\text { conscious about my job }\end{array}$ & 3 & 15 \\
\hline T9 & $\begin{array}{l}\text { It provides a more convenient way to } \\
\text { express myself }\end{array}$ & 1 & 5 \\
\hline$T 10$ & $\begin{array}{l}\text { Contributed to my socialization } \\
\text { process }\end{array}$ & 1 & 5 \\
\hline T11 & $\begin{array}{l}\text { As an educator, I became more } \\
\text { conscious about my job }\end{array}$ & 1 & 5 \\
\hline$T 12$ & I learned how to teach & 8 & 40 \\
\hline$T 13$ & I learned how to teach & 8 & 40 \\
\hline$T 14$ & $\begin{array}{l}\text { As an educator, I became more } \\
\text { conscious about my job }\end{array}$ & 3 & 15 \\
\hline$T 15$ & $\begin{array}{l}\text { I came as a student; I became a } \\
\text { teacher candidate }\end{array}$ & 2 & 10 \\
\hline$T 16$ & I learned how to teach & 8 & 40 \\
\hline$T 17$ & I learned how to teach & 8 & 40 \\
\hline$T 18$ & I learned how to teach & 8 & 40 \\
\hline$T 19$ & I learned how to teach & 8 & 40 \\
\hline$T 20$ & I learned how to teach & 8 & 40 \\
\hline
\end{tabular}

Source people (prospective teachers) responses to "As graduated one from open education faculty Turkish language and literature department what are the differences between previous and present pedagogical formation training program?" are as follow: T1, T14, T18 stated "As an educator, I became more conscious about my job" while, T2, T5, T6 pointed out "I learned teaching methods and techniques". T3, T12, T13, T16, T17, T18, T19, T20 expressed "I learned how to teach". T7 stated "He made me to look more hopefully to the future" while, T9 emphasized "It provides a more convenient way to express myself".T10 stated "It contributed to my socialization process". T4 and T15 pointed out "I came as a student; I became a teacher candidate".

Prospective teachers as graduated one from open education faculty Turkish language and literature department what are the differences between previous and present pedagogical formation training program outlined their views as follow:

T6, "I did not know any teaching methods and techniques before; but now I know methods and techniques and how to apply them."

T11, "My goal was to get the certificate for being Land Forces Command officers. I did not have any information about teaching and students. I learned how to help to the personal development of children and behave with them. I became more conscious about it."

T19, "I had my biases about this training program. But I can observe a significant difference between myself and the teaching profession after receiving training. In Academic sense, I am happy that I learned how to teach."

T20, "Of course there is $\backslash$ are difference or differences. I have to carry a very heavy responsibility upon my life. I feel like I have to be a good person and teacher in all respects. My patience has increased a lot. As a teacher I have learned what I should or should not to teach" 
Q.8. As graduated one from open education faculty, Turkish language and literature department what are your suggestion about pedagogical formation training certificate program?

Table 11. Source people (prospective teachers) answers to the $8^{\text {th }}$ questions is outlined as follow

\begin{tabular}{|c|c|c|c|}
\hline Source people (prospective teachers) & Categories & $f$ & $\%$ \\
\hline$T 1$ & $\begin{array}{l}\text { The certificate program period should be } \\
\text { short. }\end{array}$ & 3 & 15 \\
\hline$T 2$ & $\begin{array}{l}\text { There should be more focus on } \\
\text { implementations }\end{array}$ & 4 & 20 \\
\hline T3 & $\begin{array}{l}\text { It should be focused more on training, } \\
\text { more than taking certificate }\end{array}$ & 2 & 10 \\
\hline$T 4$ & $\begin{array}{l}\text { Everyone should be able to take this } \\
\text { program where they live }\end{array}$ & 1 & 5 \\
\hline$T 5$ & $\begin{array}{l}\text { This opportunity should be provided } \\
\text { unconditionally to the field of distance } \\
\text { education }\end{array}$ & 1 & 5 \\
\hline T6 & $\begin{array}{l}\text { It should not be done for money or } \\
\text { formalities }\end{array}$ & 3 & 15 \\
\hline$T 7$ & $\begin{array}{l}\text { The certificate program period should be } \\
\text { short. }\end{array}$ & 3 & 15 \\
\hline$T 8$ & $\begin{array}{l}\text { The certificate program period should be } \\
\text { short. }\end{array}$ & 3 & 15 \\
\hline T9 & $\begin{array}{l}\text { It should be given during undergraduate } \\
\text { study }\end{array}$ & 1 & 5 \\
\hline$T 10$ & $\begin{array}{l}\text { The certificate program period should be } \\
\text { longer. }\end{array}$ & 4 & 20 \\
\hline$T 11$ & $\begin{array}{l}\text { The certificate program period should be } \\
\text { longer. }\end{array}$ & 4 & 20 \\
\hline$T 12$ & $\begin{array}{l}\text { There should be more focus on } \\
\text { implementations }\end{array}$ & 4 & 20 \\
\hline$T 13$ & A program should not to be Intensive & 1 & 5 \\
\hline$T 14$ & $\begin{array}{l}\text { The certificate program period should be } \\
\text { longer. }\end{array}$ & 4 & 20 \\
\hline$T 15$ & $\begin{array}{l}\text { The certificate program period should be } \\
\text { longer. }\end{array}$ & 4 & 20 \\
\hline$T 16$ & $\begin{array}{l}\text { It should not be done for money or } \\
\text { formalities }\end{array}$ & 3 & 15 \\
\hline T17 & $\begin{array}{l}\text { There should be more focus on } \\
\text { implementations }\end{array}$ & 4 & 20 \\
\hline$T 18$ & $\begin{array}{l}\text { There should be more focus on } \\
\text { implementations }\end{array}$ & 4 & 20 \\
\hline$T 19$ & $\begin{array}{l}\text { It should not be done for money or } \\
\text { formalities }\end{array}$ & 3 & 15 \\
\hline$T 20$ & $\begin{array}{l}\text { It should be focused more on training, } \\
\text { more than taking certificate }\end{array}$ & 2 & 10 \\
\hline
\end{tabular}

Source people (prospective teachers) responses to "as graduated one from open education faculty, Turkish language and literature department what are your suggestion about pedagogical formation training certificate program?" question are as follow: T1, T7, T8 stated “The certificate program period should be short.". T2, T12, T17, T18 pointed out "There should be more focus on implementations". T3, T20 stated "It should be focused more on training, more than taking certificate". T10, T11, T14, T15 expressed "The certificate program period should be longer". T4 expressed "Everyone should be able to take this program where they live" while, T5 stated "this opportunity should be provided unconditionally to the field of distance education". T9 stated "It should be given during undergraduate study" and T13 pointed out "A program should not to be Intensive". T6, T16, T19 stated their opinion as "It should not be done for money or formalities”.

Source people (prospective teachers) opinions as graduated one from open education faculty, Turkish language and literature department about pedagogical formation training certificate program are outlined as follow:

T3, "This training program has a vital importance for the teaching profession. In this context, certification is not focused, but it should be viewed as educational programs and focused on teacher training."

T6, "I think there isn't formality side of this training program. Each system has been applied within different universities. I think that the only issue which universities has consensus on it, is the Universities fees collected for educational programs"

T10, "I do not find it right to be given within a short time; because it cannot be done in a short time as the education is 
an important issue. Giving in short time is not well. Because negatively affects students' psychology. KPSS and Pedagogical Formation Training Program Certificate cannot be combined."

T13, "I do not want to take the intensive form of this training program. Giving in practical form will be more effective and efficient for prospective teachers."

\section{Discussion and Analysis}

In considering prospective teachers answers to the first question it can be get that teachers' aim in taking pedagogical formation training for \% 5 was "opportunity assessment", \%50 "teaching certificate", \% 35 "learn how to implement", \% 5 "To address the lack of formal education", while \%5 stated "to be officer". Stating "opportunity assessment" represents that the teachers' candidate considered it as an opportunity for find out a job. The candidates who stated "teaching certificate" regarded the course as chance to be a teacher, so this training program help them to get 'necessary documents for application'. "Learning how to implement" and "To address the lack of education". In fact by being graduated from open education faculty, they aim to do the best to remove the deficiencies of being practical, hence it is thought that they plan to learn the teaching profession in practical way.

Source people (prospective teachers) in answering to the second question regarding teaching efficiency and possessing the characteristics of qualified teachers $\% 85$ percent said 'pedagogical formation is necessary', $\% 5$ expressed "necessary but not enough";so, they emphasized the limitation of pedagogical formation training. \% 10 believed there is "no need" for that. Between different participants responses the idea of T11 for taking pedagogical formation training in order to have necessary certificate 'to be officer' is astonishing. Other participant T 20belief regarding 'we will learn through our experiences in life' represents that regarding the limitation of such program, he/she is negatively affected by it and looks for different way to improve herself/himself.

Source people (prospective teachers) in answering third question considering "what are the most significant limitation of Turkish language and literature education?" \% 25 stated "implementation, and lack of knowledge and skills", also \% 25 stated "Theoretical and rote tests -solving approach". In this respects being based on test solving characteristics of distance education, lacks the face to face education and opportunities in the application of theoretical knowledge. \% 5 pointed out "lack of face to face education and field information". Considering this views rather than face to face education book-oriented concept of education or lack of opportunities to get benefit from the application of open education faculty are emphasized by the participants. \% 10 stated "the lack of written and oral skills" which means the main cause is regarded as assessment system characteristics in learning language in case of speaking and writing. The "lack of visual course materials" stated by $\% 5$ of participants. Especially textbooks visual tables, shapes and desire for enriched graphics have been concentrated between participants. The participant referred to the lack of visual aspects of textbooks; so, it affected the course negatively. \% 10 pointed out "Lack of interest and talent". All these opinions show that accepting students by low scores is because of their needs for studying at university, hence there are necessities rather than the interests and abilities. \% 10 of participants indicated "the lack of implementations". Especially they mentioned that "open education faculty" education must be based on implementation and application, in other case the information will not be permanent. \% 5 revealed there is "no lack". Having such opinion is because of "being teacher" so they didn't consider any deficiency. In general lack of skills, information and implementation or lack of written and oral application had been considered as effective cause which must be reduced.

Source people (prospective teachers) views in considering "what can be done to reduce the deficiencies on the way of Turkish language and literature education? "are as follow: \% 30 answered "put emphasis on implementation". It can be seen that one of disadvantages of distance education are the lack of implementation because of weak teaching and lack of learning setting. \% 30 mentioned "should be given importance to written and oral representations". Have problem in the basic language skills as listening, speaking, reading and writing and have difficulty in expressing themselves, cause to not feel socialized. While \% 5 stated that "should accept the students with high score", they emphasize that the score of YGS should be increased. It is advocated that the quality of education is especially related with scores. Also \% 5 referred to "Student quotas should be reduced". Especially Student quotas in Turkish language and literature education affected the quality of education. \% 5 uttered "there must be diversity in teaching methods and techniques". There are some kind of problems dealing with Turkish language and literature education; therefore, it is emphasized that this situation should be treated in pedagogical training setting. \% 20 of participant claimed that "Online courses should be provided" because of the lack of implementation, information, writing and speaking skills. $\% 5$ of participant stated that they have "no idea" and it is because of their wishes to be an officer; so, not being a teacher can be considered as the cause of their opinions and thoughts.

Source people (prospective teachers) in answering to "what are the contributions of special method course of pedagogical formation training program on you?" \% 25 stated there must be some attempts to "Increasing participation in class discussions and enhancing self-confidence and motivation". As it is shown open education 
students comparing with students of formal education have some disadvantages. Especially their point of views toward society, economical problems and the lack of practices and applications are the causes of such views. $\% 30$ of participants wanted "Effective and efficient learning lessons processing". This response shows that except the teacher training school other programs have some shortcomings in teaching profession. Also $\% 40$ of participant stated that with the help of "Teaching methods and techniques" learned teaching methods and could apply it for their teaching profession. While \% 5 of participants expressed "no idea". Like other responses, the same participant answered with same questions to all questions. As referred before the aim of participants of taking pedagogical formation program considered as finding "different job" or taking "formality document".

Source people (prospective teachers) in answering to the following question "what are/is the contribution/s of teaching methods course on you?" \% 55 stated "I gained experience, I beat my excitement". As a consequence of the lack of teaching methods such opinions are started off. Parallel with this view \% 35 stated that "I experienced and I understand the importance of the teaching profession". The emergence of this opinion is on the account of the lack of profession in their field of study. $\% 5$ of participants who have experiences stated that "I do not take the course because of being exempted". While \% 5 pointed out "It has contributed to my personal development", so pedagogical formation program had some benefits for these participants.

Source people ( prospective teachers), answers to the "as a person graduated from open education faculty and Turkish language and literature departments what are the differences between pervious and present life after pedagogical formation program?" were as follow: \% 15 stated that "As an educator, I became more conscious", So pedagogical formation program influenced their profession perception. \% 15 of participants mentioned that "I learned teaching methods and techniques"; so, with the help of pedagogical formation program they had been improved their teaching methods and techniques. Also \% 40 of participants stated that "I learned how to teach", on this account they consider this program very necessary for development of their profession. Likewise, in parallel with this opinion they stated that "I came as student; I became a teacher candidate", they got high self confidence and motivation. Also in this context \% 5 pointed out positively, "It made me look more hopeful to future". \% 5 of participants referred "It provides a more convenient way to express myself"; therefore this program helped them to improve their written and oral presentation skills.

Especially $\% 5$ expressed that they rely on face to face education because of its significant effect on the process of socialization. As I referred before $\% 5$ pointed out they joined the program for finding "Another job" but again they uttered that "I became more conscious as an individual".

Source people (prospective teachers) in answering to the question "what are your suggestion to pedagogical formation program as a person graduated from open education faculty Turkish language and literature department ?" \% 15 affirmed that the time of program should be short. The reason behind this idea is economical problem and being far from family members, while \% 20 asked for "there should be given more weight for implementation and applications". It means this program relies less on implementations and applications which are the main reason of deficiencies in open education programs. \% 10 of participants stated that "Certificates should not be focused; but the education". This means the main item which is emphasized in the program "formality certificate" is influenced their training negatively. \% 20 stated that "the certificate program time should be longer". The considering points are, they look for the way to enhance knowledge and skill and to improve the teaching profession. While $\% 5$ stated "Everyone should be able to get this program wherever they live", it represents that because of financial or other problems joining home city participation in the program will be more useful and effective. Also \% 5 mentioned that "This opportunity should be provided unconditionally in the field of distance education" too. So, creating opportunities for graduated students will be more reasonable and effective. In addition to $\% 5$ of participants uttered that "it should be given during BA program". The education will be given during License program will save teacher/student time. $\% 5$ with asking for "a program should not be concentrated" believed that with such program they will not catch their goals. \% 10 stated "it cannot be done because of money or formalities". This represents students' stressed feeling in the case of economical difficulties to pay the fee. Also with giving this program widely the number of students will be increased so it made them to feel anxious about 'the rise in KPSS basis scores".

\section{Conclusions and Recommendations}

At the end of study prospective teachers stated some limitations in distance education; so they have positive look toward pedagogical formation program to catch their goal. With pedagogical formation they learn the implementations, teaching methods and learning techniques. In addition to teaching profession information was limited before applying this program. With being monetary and formality based they feel inconvenient, so they are looking forward intensive program. This certificate with its special teaching methods course will contribute to teaching implementation, methods and techniques. The most important deficiency in Turkish language and literature education are the lack of methods, 
speaking and writing skills and being based on rote learning and test solving approach. So, they think that, it can be solved by online education. Moreover, as being individuals graduated from distance education the number of students quotas for Turkish language and literature should be reduced and with increasing the base points the quality will be enhanced.

This research in general considered Anadolu university open education faculty, Turkish language and literature department graduated students views about pedagogical formation training program certificate's advantage and disadvantages. Therefore in order to find the solution to the limitation of this system and to consider the positive and negative aspects of distance education of open education faculty, Turkish language and literature graduated students' experiences, this study aimed to contribute to the study. In this context, it will contribute to the other departments of Anadolu university open education faculty.

In order to find out Anadolu university open education faculty, Turkish language and literature department graduated students' views about pedagogical formation training program certificate and special teaching methods course and Turkish language and literature were considered. Based on the findings and results the following recommendations are outlined:

- Because of applying Pedagogical formation training program certificate differently in some universities, YÖK should consider the case of being based on "money and formalities", and should not allow the opening of this training program everywhere. In particular, priority should be given to qualified universities.

- Pedagogical formation training program certificate can be prepared and set extensively instead of conducting in intensive programs.

- Anadolu university open education faculty, Turkish language and literature department instead of relying on test based assessment system and application-oriented, can take into account the self-expression skills to improve students' writing skills. So, the open-ended questions should be developed in a system. With this regard the ÖSYM issue for initiating the open-ended examination system is to apply pilot studies; therefore, with analyzing pilot studies new concepts can be developed.

- In order to eliminate the limitation of distance education in Turkish language and literature which plays an important role in the development of the individuals. Distance education as a need of information age and in accordance with constructivist approach should be developed; so, online education opportunities and learning materials and tools should be enhanced and enriched.

\section{References}

Baturay, M., \& Bay, Ö. F. (2009). Demographic Characteristics of the Students That Chose Distance Education, Dicle University Journal of Ziya Gökalp Faculty of Education, 13, 17-26.

Bayram, D. (2010). The comparison of professional development programs for science and physics teachers in Turkey, the USA, Japan, England and Australia. Ankara University University Institute of Educational Sciences. Unpublished PhD Thesis.

Bulut, M. (2012). Analysis of M. Fuad Koprulu's Turkish-Literature Coursebook Titled "Millî Kiraat" in Terms of Teaching Turkish and Turkish Language and Literature. Ataturk University Institute of Educational Sciences. Unpublished PhD Thesis. Erzurum.

Büyüköztürk, Ş., Kılıç, Ç. E., Akgün, Ö. A., Karadeniz, Ş., \& Demirel, F. (2013). Science Research Methods. Ankara: Pegem Akademi Yayıncılık.

Cobb, V., L., Darling-Hammond, L., \& Murangi, K. (1995). Teacher Preparation and Professional Development in APEC Members: An Overview of Policy and Practice. In L. Darling-Hammond and V. L. Cobb, (Ed.). Teacher Preparation and Professional Development in APEC Members: A Comparative Study (pp. 1-16). Washington, DC: U.S. Department of Education. See ED 383683.

Çetişli, İ. (2006). The Place and Meoning of Literary Text In Literature Education, Millî Eğitim Dergisi Edebiyat Eğitimi Özel Saylsı, 169, 75-84.

Darling-Hammond, L. (2006). Constructing 21st Century Teacher Education. Journal of Teacher Education, 57, 300-321.

Gurbuz, F. (2014). Students' Views on Distance Learning in Turkey: An Example of Anadolu University Open Education Faculty. Turkish Online Journal of Distance Education-TOJDE, 15(2), 239-250.

Gurbuz F. (2015). The Views of Pre-Service Teachers Who Take Special Teaching Course Within the Context of 
Pedagogical Formation Certifica Program About Micro-Teaching Method and A Physics Lesson Plan. International Journal on New Trends in Education and Their Implications, 6(4), 1-17.

Gurbuz, F. (2016). Physics Education: Effect of Micro-teaching Method Supported by Educational Technologies on Pre-service Science Teachers' Misconceptions on Basic Astronomy Subjects. Journal of Education and Training Studies, 4(2), 27-41.

Güzel, A. (2006). Aims of Literature Education and Methods, Techniques and Exemplary Implementations for TheseAims. Milli Ĕgitim Dergisi, 169, 85-106.

Henri, F. (1990). Distance Teaching and Computer Aided Distance Education and Communication, (Çev.: L. Özbilgin). Eğitim ve Bilim, XIV, 21.

Hizal, A. (1983). Written Distance Learning Processes and Materials: Approach from the Viewpoint of Educational Technology. Ankara: University Faculty of Educational Sciences Publishing, No:122.

Höçük, S. (2011). The factors affecting academic achievement of Ankara University distance education students. Ankara University University Institute of Educational Sciences. Unpublished Master Thesis.Ankara.

İşman, A. (1998). Students Preception of A Class Offered Through Distance Education. Doctoral Thesis, Ohio University, Athens, Ohio, USA.

Kavcar, C. (1999). Literature and Education. Ankara: Engin yay.

Kaya, Z. (2002). Distance Education. 1. Baskı. Ankara: Pegem A Yayınc1lı.

Moore, M. G. I., \& Kearsley, G. (1996). Distance Education: A Systems view. Wadsworth Publishing Company.

Özbay, M. (2002). Turkish Training in Terms of Cultural Transmission. Türk Dili Dergisi, 602, 12-120.

Özkul, A. E. (2009). Distance Education for Unimpeded University. Unimpeded University Meeting, Ankara.

Senemoğlu, N. (1992). Comparison of Primary Teacher Training Programme and Instructor of English Students on the Primary Teacher Training Program Opinions-England and Turkey in the UK. Hacettepe University Faculty of Education. ANKARA.

Taşdelen, V. (2006). Literature Education: A Hermeneutical Approach. Literature education and training Special Issue 169. say1, Ankara: MEB Yay.

Yıldırım, A., \& Şimşek, H. (2013). Qualitative Research Methods in Social Sciences. (9th ed.). Ankara: Seçkin Yayıncılık.

This work is licensed under a Creative Commons Attribution 3.0 License. 